\title{
UM EXPERIMENTO DE HISTÓRIA ORAL SOBRE VIOLÊNCIAS ENTRE TRAVESTIS E POLICIAIS NA CIDADE DE SÃO PAULO A PARTIR DA DÉCADA DOS 1990
}

\author{
AN ORAL HISTORY EXPERIMENT ON VIOLENCE BETWEEN \\ TRANSVESTITES AND POLICE OFFICERS IN SÃO PAULO CITY FROM THE 1990 S
}

\section{RESUMO}

As travestis brasileiras sofrem violências e violações de direitos que partem de várias direções. Uma delas é a que vem da área da segurança pública. Nesse caso, há considerável bibliografia sobre o período mais recente e o da ditadura militar brasileira, o que não acontece para o período pós ditadura até os 2000, sobretudo para a cidade de São Paulo (SP), meu foco. O objetivo deste artigo é tentar cobrir essa lacuna e observar as mudanças ocorridas até os dias de hoje. Foi utilizada a metodologia da história oral, a partir de entrevistas realizadas com travestis que começaram a se prostituir nesta cidade ainda nos anos 1990. Das lembranças das entrevistadas, em que pese a diminuição da violência mais contundente ao longo dos 2000, se observa um padrão de práticas policiais compostas por violações de direitos e corrupção, que é agravado pelo fato dos agentes de segurança pública, em geral, estarem imersos numa moldura cultural heteronormativa e estigmatizante em relação às travestis.

Palavras-chave: Travestis. Policiais. História oral. Transfobia. Violência. Violações de direitos.

\begin{abstract}
Brazilian transvestites suffer violence and rights violations deriving from various diretions. One comes from the área of public security. In this case, there is a considerable bibliography about the most recent period and of the Brazilian military dictatorship, which is not the case for the period after of the dictatorship until the year 2000, specially for the city of São Paulo (SP), my focus. The objective of this article is to try to cover this gap and observe the changes that have occurred up until this day. The methodology of oral history was used, based on interviews with transvestites who began to prostitute themselves in this town still in the 1990s. From the recollections of the interviewedes, in spite of the decrease of the most forceful violence during the 2000, there is a pattern of police practices composed by violence, rights violations and corruption, which is aggravated by the fact that public security agents are usually immersed in a heteronormative and stigmatizing cultural framework in relation to transvestites.
\end{abstract}

Keywords: Transvestites. Police officers. Oral history. Transphobia. Violence. Rights violations.

Cassiano R. M. Bovo

Anistia Internacional Brasil. Pontifícia Universidade Católica de São Paulo (PUC-SP). E-mail: cassiano. bovo@gmail.com 


\section{Introdução}

Eu acho que...porra, será queé difícil a pessoa respeitar uma pessoa que queira se vestir ou se comportar, que quer viver do jeito que ela se sente bem, entendeu? Só isso! Que quer passar um batom e se vestir com uma roupa de mulher e se sentir bem assim? (Lorry).

Se há um grupo de pessoas na sociedade brasileira que ainda sofre um cruel processo de exclusão são as travestis ${ }^{1}$ Em geral, suas vidas desde cedo revelam uma sucessão das mais variadas violências e violações de direitos. Muitas delas são abandonadas e/ou agredidas logo cedo pela sua própria família e rejeitadas na escola. As empresas lhes fecharão as portas (muitas vezes por parte dos mesmos homens que as procuram para fazer programas). A prostituição acaba sendo a saída para a maioria delas, num mercado já dominado por esquemas de tráfico de pessoas e controle territorial e habitacional, por parte de cafetinas e cafetões. Também, a não aceitação de seus nomes sociais nas mais variadas instituições, além do despreparo no atendimento no sistema de saúde. Riscos, os mais variados, estão sempre à espreita: na área da saúde, decorrentes dos implantes, aplicações de silicone e ingestão de hormônios, assim como o HIV, além dos perigos nas ruas.

Dentre tantas violências, há ainda a que parte dos policiais, no âmbito do sistema de segurança pública, nas ruas, camburões, delegacias e no sistema carcerário. Como vários relatos, assim como a literatura a respeito, apontam as violações de direitos e crueldades, nessa área, acontecem desde que as travestis passaram a utilizar a prostituição como forma de sobrevivência, a partir da década dos 1970. Rafael Freitas Ocanha, dentre outros, por ex., em várias obras² tem se debruçado sobre a repressão policial em relação às travestis na cidade de São Paulo no período da ditadura militar, quando, sob a alçada dos delegados Sergio Richetti e Guido Fonseca, do Cel. Erasmo Dias como Secretário de Segurança do Estado de São Paulo, dentre outros, as travestis eram recolhidas às delegacias em decorrência dos chamados arrastões, rondões ou blitzes. Se utilizava largamente da lei de vadiagem e atentado ao pudor, sempre legalmente questionadas. Era o início da cruzada de controle e repressão das forças de segurança pública contra as travestis de par com o julgamento moral de parte considerável da sociedade.

Passado o período, esse cenário pouco se alterou; pelo contrário, a escalada da violência policial contra as travestis se acirrou ao longo da década dos 1980 e 1990³. Embora haja poucas obras para esse período, os relatos existentes ${ }^{4}$, assim como

1 Utilizo o termo travestis para abarcar as mais variadas configurações de identidade de gênero do universo trans em decorrência de sua larga utilização na sociedade brasileira, sem preocupações, neste espaço, de adentrar na discussão das mais variadas possibilidades linguísticas.

2 Pela abrangência e profundidade recomendo sua dissertação de mestrado: Ocanha (2014).

3 Veja o capítulo Travestis tipo exportação in Trevisan (1996).

4 Veja por ex., Dois travestis, uma advogada: três depoimentos vivos sobre o sufoco. Jornal Lampião da Esquina, edição extra n.3, 1980. Temos também o impactante depoimento de Indianare Siqueira que 
etnografias respeitadas, para várias localidades do país, o confirmam5. Para a década dos 2000 em diante já há um número considerável de obras a respeito.

Um dos objetivos deste artigo é tentar preencher a lacuna existente no que diz respeitoà década dos 1990, sobretudo na sua segunda metade. Como lembra Thompson (1992) um dos propósitos da história oral é obter informações por meio de entrevistas quando faltam documentos, assim como reforçar ou comprová-los. Porém, mais do que isso, minha intenção é, também, abordar as práticas policiais em relação às travestis na cidade de São Paulo até os dias de hoje, ressaltando possíveis mudanças, inclusive verificando se o conteúdo da bibliografia existente para as mais variadas localidades se aplica a essa cidade; enfim, trata-se também de evidenciar o que já existe.

Procuro atingir os objetivos em pauta a partir das narrativas e recordações com base nas entrevistas que realizei com quatro travestis que trabalharam nas ruas da cidade de São Paulo a partir dos anos 1990.

Espero, dessa forma, contribuir para enriquecer e confirmar (ou não) o que já existe a respeito do assunto assim como cobrir lacunas, principalmente no que diz respeito à cidade de São Paulo.

Assim, este artigo está estruturado da seguinte maneira: na primeira seção trato da metodologia utilizada; na segunda, abordo o período dos anos 1990 e 2000; na terceira, o período mais recente, com ênfase nas mudanças ocorridas nas relações travestis x policiais, sob a ótica daquelas; na quarta, aponto outras questões dessa interação e, por fim, teço as considerações finais.

\section{Metodologia}

O caminho não é esse, gente! O caminho é ajudar e ver o que é que está acontecendo com essas pessoas (Lorry).

Se o meu objetivo é conhecer as práticas policiais em relação às travestis da cidade de São Paulo, num período mais longínquo, uma vez que a literatura existente se refere primordialmente ao período recente, assim como preencher lacunas em relação ao que se conhece, isso só pode ser feito se entrevistarmos as pessoas envolvidas. Porém, dificilmente policiais contarão o que aqui se aborda. Também, em geral, não há testemunhas assim como dificilmente isso se vê na mídia, ao menos nesse nível de detalhe. Sendo assim, apenas travestis que tenham tido larga vivência nas ruas, nesse período, poderão compor esse quadro. Por isso, entrevistei travestis que começaram a se prostituir ainda na década dos 1990. Trata-se de registros vivos de algo que só elas podem tornar presentes e fazer com que tenhamos conhecimento.

sofreu as mais variadas violências e opressões por parte de policiais civis e militares. Veja https://www. facebook.com/indi.siqueira/posts/561252514059561.

5 Por ex. Kulick (2008), Silva (1993), Florentino (1998), Oliveira (1994), Oliveira (1997), dentre outros, assim como a obra autobiográfica Albuquerque \& Janelli (1995). 
É justamente nessas situações que a história oral emerge como interessante recurso metodológico. Paul Thompson, seu precursor, lembra três importantes contribuições desse procedimento: a informação (geralmente única) sobre o passado, a consciência individual e coletiva sobre os fatos e a possibilidade de se captar a evolução ao longo do tempo (Thompson, 1992), sempre lembrando que a história oral não se esgota em si mesma e pode ser utilizada de formas diversas em projetos dos mais variados tipos. Muitas obras posteriores ao trabalho do autor em pauta aprofundaram a discussão e aperfeiçoaram os usos e a metodologia da história oral. Dentre as mais variadas delas, produzidas no Brasil, sobre o assunto, minha referência é Meihy \& Holanda (2015) que tratam dos procedimentos básicos de uma pesquisa que utiliza recursos da história oral.

É comum, nas ciências sociais, as entrevistas se constituírem num dos recursos a subsidiar a análise; na história oral as entrevistas são a razão de ser do estudo, é lugar central e tudo gira em torno de seus conteúdos: "Enquanto a entrevista subsidia outros tipos de documentos, no caso da história oral o que se pretende é a centralização das narrativas que se constituem, desde sua concepção, em objeto central das atenções" (Meihy \& Holanda, 2015: 64).

Não se trata, também, de ver cada entrevista como um conjunto de experiências isoladas das demais: "É a totalidade organizada das entrevistas que interessa. O reforço dos argumentos ou a oposição deles faz com que as entrevistas se entrelacem favorecendo conclusões que as justificam" (Meihy \& Holanda, 2015: 118)6.

Assim, este artigo gira primordialmente em torno das entrevistas realizadas com quatro travestis com idades que fazem com que com tenham vivenciado a prostituição, nas ruas da cidade de São Paulo, ao menos em parte dos anos 1990, de forma que todas elas, de alguma forma, vivenciaram um período considerado, em termos de Brasil, de consistente violência policial ${ }^{7}$ e, sendo assim, se torna possível verificar possíveis mudanças nas décadas seguintes. Os conteúdos apresentados por cada entrevistada serão sempre apresentados de maneira entrelaçada (na perspectiva da citação acima), na confrontação ou nas semelhanças, nunca de maneira isolada uma da outra. A história oral tem na repetição uma forma de validação do que se apresenta:

Pensando que a memória coletiva se dá exatamente na repetição de fatos narrados é que se advoga o respeito à apreensão dos acontecimentos e a sua transposição do código oral para o grafado. Interessa não as palavras em si, pois não é cada palavra exatamente como foi dita que vale, mas o seu significado no conjunto da dissertação de alguém em situação de entrevista e na conjunção de outros textos estabelecidos na mesma perspectiva (Meihy \& Holanda, 2015: 124).

6 "Não há sentido social em história oral de pessoas sozinhas" (Meihy \& Holanda, 2015: 118).

7 Por exemplo, em São Paulo, elas lembram-se, em especial, de um policial militar: "Era o Garcia... quando ele passava, não ficava uma, ele judiava, barbarizava” (Flávia, para finais dos 199o). 
Todas as nossas entrevistadas trabalharam na prostituição, na maior parte de suas vidas. Laura e Lorry são as mais antigas; ambas iniciaram por volta de 1992, sempre trabalhando na região central de São Paulo, porém Lorry, durante alguns anos, trabalhou simultaneamente em Campinas e morou na França nos anos 2004 e 2005. Já Suzi e Flávia num período posterior. A primeira começou a se prostituir aos doze anos em Belém do Pará e chegou a São Paulo em 1997, trabalhou a maior parte do tempo na Av. São Miguel (zona leste da cidade), com um intervalo (de 2005 a 2008), quando ficava, simultaneamente, na Praça da República e em Arujá, cidade da Grande São Paulo $^{8}$. Já a segunda iniciou em 1999 e sempre trabalhou no centro de São Paulo. Todas ainda fazem programas, mas de maneira esporádica.

Também todas elas têm outro traço em comum: participam, ou participaram, do Programa da Prefeitura de São Paulo chamado Transcidadania, criado na gestão do Prefeito Haddad, o que possibilita, além da bolsa recebida, dar continuidade aos estudos na rede pública, no EJA (Educação de Jovens e Adultos), e realizar cursos técnicos.

Como se vê, todas elas se enquadram dealguma maneira no quesito da interação com policiais desde a década dos 1990. Para chegar às entrevistadas fiz vários contatos, sobretudo na região central de São Paulo, e utilizando um sistema de indicações entre elas, seis aceitaram ser entrevistadas, o que de fato ocorreu, porém, duas delas se recusaram a assinar o Termo de Consentimento Livre e Esclarecido (TCLE), condição sine qua non para publicação de suas falas; assim, fiz com que suas entrevistas servissem apenas como referencial para compor o quadro da situação, porém não utilizo citações e nem faço menções explícitas a elas, neste artigo.

Ao contatá-las, expliquei meus objetivos e após aceitação, combinei o local (quatro delas em bares da região central de São Paulo e duas em espaços de alimentação de shopping centers) e realizei as entrevistas, entre 11 de março a 24 de abril, com uma duração média de 22 minutos. Intencionalmente eu direcionei as entrevistas perguntando diretamente o que eu queria saber: pedi que elas contassem experiências de todo tipo vivenciadas por elas, ou por outras (o que se fez, falou, viu, ouviu, ficou sabendo), envolvendo policiais (militares e civis, incluindo delegados, investigadores, carcereiros etc., do gênero masculino), nas ruas, camburões, delegacias e sistema prisional, sempre - embora às vezes de forma imprecisa - com a preocupação de datar os acontecimentos, o que permitiu comparações ao longo do tempo, de modo a se observar as mudanças, principalmente em relação aos dias de hoje.

Em seguida, todas as entrevistas foram literalmente transcritas. A partir de cada transcrição, realizei a chamada textualização (transformação da transcrição num texto direto, sem entrevistador e entrevistado) e finalmente criei um texto final, chamado de transcriação, que é a entrevista transcrita transformada num texto de

8 Suzi bem cedo teve uma experiência com um policial: "Lá em Belém do Pará...eu tinha...eu ia fazer 15 anos, tinha 14 para 15 anos e saí com um policial. E ao mesmo tempo que eu saí com ele, ele não me pagou o programa, naquele tempo o programa era 5 reais...e eu cobrei para ele o programa de 5 reais e ele não me pagou. E ele falou que se eu falar para outra pessoa ele ia me matar e me bateu bastante, na praia do Cruzeiro, em Icoaraci...eu estava de 14 para 15 anos". 
minha autoria, em outra ordem, de acordo com meus objetivos interpretativos e de estruturação do artigo, mas mantendo os seus conteúdos originais. Como afirma Meihy \& Holanda (2015: 136):

A transcriação é assim um fundamento-chave para a história oral, pois, sendo ela aplicada aos estudos de grupos, comunidades e indivíduos, abandona os estritos caminhos da racionalidade e se abre às convenientes dimensões subjetivas. A noção de transcriação ganha novos sentidos na história oral, pois sugere a fatalidade da transcriação como ato de recriação para comunicar melhor o sentido e a intenção do que foi registrado (itálicos no original).

Se o texto transcriado foi crucial para as minhas interpretações, todas as citações que apresento são reprodução literal das entrevistas transcritas, com pequenos e pontuais ajustes, sem alteração do teor de seu conteúdo9 ${ }^{9}$ O objetivo desse procedimento foi o de preservar a originalidade de suas falas, sem interferências de minha parte ${ }^{10}$. Tive um segundo contato com as entrevistadas para entregar as suas entrevistas na forma de transcriação e aproveitei para dirimir algumas dúvidas sobre o conteúdo e, sobretudo, para a assinatura do TCLE. Com exceção de Suzi, os nomes das entrevistadas neste artigo são pseudônimos escolhidos por elas.

Uma das dificuldades, e fonte de polêmicas, é a força da evidência das entrevistas quando comparadas com documentos formais, mais utilizados na historiografia, porém, a história oral tem como objetivo, em geral, cobrir a carência de fontes documentais. Esse é justamente o meu caso. Mas há “(...) possibilidades de enganos, mentiras, distorções e variações dos fatos registrados e conferidos por outros documentos" (Meihy \& Holanda, 2015: 60). Assim, se torna necessária a verificação das inconsistências, incoerências ou exageros (Thompson, 1992), típicas desse caminho metodológico ${ }^{11}$. Recomenda-se, então, procedimentos de checagem e estabelecimento de parâmetros, que, no meu caso, contaram com as obras que envolvem as relações travestis x policiais, mesmo que a maioria delas se trate de outras localidades que não São Paulo, assim como os relatos informais, conversas e vivência com travestis na cidade de São Paulo, na busca da evidência e comprovação.

É evidente que não se trata de transpor o que aconteceu com as quatro travestis entrevistadas para o universo de travestis brasileiras e, sobretudo, da cidade de São Paulo. Pretende-se apenas lançar luz sobre práticas realizadas por policiais que têm algum grau de generalidade, que revelam não serem incomuns.

9 Por ex., quando se diz “pra”, utilizei para; “né”, não é; “tá”, está, e assim por diante.

10 Esse é o procedimento utilizado também por Ferreira (2016).

11 É importante registrar, por outro lado, as incoerências e inconsistências também das próprias fontes documentais, algumas, inclusive, podem ter sua validade questionada, como lembra Thompson (1992). 


\section{Travestis x Policiais na perspectiva das entrevistadas: décadas dos 1990 e 2000}

Como eles tratam uma trans? Como se fosse bicho. Que a realidade é essa? (Suzi)

As relações com policiais (de várias instituições e tipos) estão impregnadas nas subjetividades das entrevistadas, por meio das mais variadas experiências vividas, além de tudo que viram e ouviram. Sobressaem-se as situações de violência, tanto a física como a simbólica (Bourdieu, 1999), entendida aqui como omissão, descaso, humilhações, agressões verbais, chacotas, provocações etc.

A violência que parte de discursos ${ }^{12}$ de policiais é relatada por todas as entrevistadas: "(...) lá na esquina os policiais sempre passavam lá e chamavam a gente por nome: 'Vai jogar bola Paulão', 'Vai virar homem', 'Vai criar vergonha' (...) eu era muito hostilizada na época (...) não cheguei a apanhar, mas fui muito hostilizada aqui em São Paulo” (Suzi); “(...) antigamente eles chamavam de João, filha da puta, vai dar neto para sua mãe (...) toma jeito, vira homem. Já teve gente que se tivesse poder de exterminar, exterminava todas...e eles não falam de gay, de gay...eles falam da gente... trans mesmo...”(Flávia); “(...) uma vez que eu fui assaltada, e fui na delegacia fazer a denúncia e eles riram da minha cara. Me mandaram procurar um outro distrito...Eu saí muito humilhada de lá" (Laura, ano 2000)³. E:

(...) a gente vai esperar o que de um país onde você vê, durante o dia, pessoas fardadas, não só policiais, pessoas que trabalham seriamente a ficar apontando travesti e cadeirante, às vezes porque a pessoa é negra, porque a pessoa é gorda...e ficar sorrindo... isso é tipo de coisa que eu fico muito perturbada (...) Ficar com sorrisinho sarcástico, eu acho que não tem por quê (...) (Lorry).

Em termos de violência física os discursos das travestis entrevistadas são repletos de menções a tapas, socos e golpes de cassetete:

Eu estava com dinheiro, eu tinha trabalhado bem, estava com um bom dinheiro, daí eu peguei o dinheiro e as minhas coisas tipo de valor e dei para uma amiga minha, fiquei só com o telefone e falei: 'leva com vocês', porque eu sabia que eles iam querer, porque eles já tinham olhado a minha bolsa e que eles iam querer. Quando ele veio olhar minha bolsa de novo, que ele viu que eu estava sem o dinheiro, ele tinha me revistado antes e viu que eu estava com

12 Para Foucault (1979), ao abordar o conceito de dispositivo, discursos são, também, práticas.

13 Geralmente as travestis não denunciam ou fazem B.O. quando são roubadas ou têm seus direitos violados, a não ser em casos de maior gravidade. São bastante descrentes nas instituições em geral, sobretudo na área da segurança pública. 
dinheiro - que eu tinha dado para minha amiga -, quando ele viu que eu não estava, ele deu um tapa no meio da minha orelha, que eu vejo passarinho até hoje (Laura).

Uma vez eu estava indo para casa, quando morava na Casa Verde. Estava indo no carro, bêbada, cheiradona, na época, 2006. Tinha uma blitz e eu parei, ele pediu para parar e eu parei, lógico, e quando eu desci o policial me tratou mal, já me olhou e viu que eu era uma trans, já me tratou com aquele olhar...e perguntou para mim: 'de quem é esse carro?' Eu estava "daquele jeito" e falei: 'é seu!. Ele me deu um tapão na cara. Aí, tinha outro que estava com ele, o superior dele, e falou que ele não podia fazer aquilo. Foi o branquinho que me bateu.... (Flávia, para o ano 2006, mais ou menos).

Muitas meninas apanharam bastante, perdiam bolsa, sapato. Eu mesma...ficaram com um camburão correndo atrás de mim, eles atrás de mim com um camburão e eu na chuva correndo e eles atrás, entendeu? Se eles acelerassem, eles podiam me matar a hora que eles quisessem..." (Lorry) ${ }^{14}$.

Kulick (2008) relata, na sua etnografia para a cidade de Salvador (realizada em 1996 e 1997), a prática do corredor polonês (ou corredor da morte), única menção ao fato que conheço. A prática também foi relatada pelas entrevistadas:

Foi aqui no Centro, eles pegaram a gente aqui na Amaral Gurgel. Pegou um monte e levou lá para delegacia, lá na...acho que na Augusta, acho que em um predinho ali. E pôs em fila, assim... todo mundo. Tinha uma escada para subir, na escada embaixo ele mandou formar uma fila, e a gente formou...e teve umas que ficaram rindo, uma com a outra...E um policial parou perto de mim e eu tinha acabado de bombar não é? - colocar silicone na bunda - e eu falei 'bate em qualquer lugar menos na bunda' (risos). Ficava batendo, uma por uma...tinha que mostrar o documento. E eu falei para ele: 'por favor não bate na minha bunda, que eu tinha acabado...' e ele bateu, até hoje tenho a marca. Eu falei para ele não bater na minha bunda.... (Flávia, para o ano 2003).

(...) na década de 9o...eu mesma tenho marca no meu corpo... que eu tinha acabado de fazer meu silicone, fazer meu corpo...a gente estava num bar, tudo numa boa...eles chegavam de repente e fechava o bar e às vezes fazia o corredor da morte... que a gente tinha que passar...Já passei no corredor da morte...dentro do bar.

14 Diante de meu questionamento se ela tinha feito alguma coisa para os policiais correrem atrás dela, Lorry afirma: "Não, bem pelo contrário, eu sempre trabalhei de calça jeans, blusa e um sapato, igual você está vendo aqui. Eu nunca trabalhei de seio de fora, nada.... 
E a gente apanhava bastante...eu mesma tomei borrachada no quadril ${ }^{15} \ldots$... tal...nesse corredor da morte...O corredor da morte... vários policiais com cassetete na mão e.... assim, cada uma vai passando...entendeu? Isso existe já há bastante tempo... mas, assim...depois da década de 90 continuou acontecendo...eu não esqueci realmente, igual eu estou falando com você agora aqui, não consigo nem falar direito... (Lorry) ${ }^{16}$.

Também, Kulick (2008) menciona a prática rotineira, por parte de policiais militares, de colocar várias travestis em um camburão e, no caminho, realizar sessões de tortura e para soltá-las em locais bem distantes e escuros, muitas vezes com a realização de espancamentos, ainda, no local. Ao que parece essa prática parece ter sido comum também na cidade de São Paulo:

Eu já fui deixada várias vezes, não só eu como todas, em lugares abandonados (...) ainda mais na época de 9o, entendeu? Era muito ruim trabalhar. Naquela época levavam a gente para uns lugares escuros, deixavam a pé, rasgavam, jogavam peruca fora. Trabalhei muitos anos em Campinas, deixavam as meninas, antigamente, lá no tal do Pico das Cabras, onde ninguém passava, entendeu? Jogavam peruca, jogavam roupa no mato para você não achar mesmo a roupa, ir embora pelada, às vezes; já fui embora pelada (Lorry).

(....) teve uma vez, que foi, eu acho...não, foi a Rota, foi aqueles carros que eram escuros, que é tudo tampado, jogaram a gente dentro do camburão. E a gente...eles começaram a andar, andar, andar, andar, com a gente dentro, dentro daquele carro, a gente apertando, a gente, meu Deus do céu, já apavorado, já pensando no pior, não é? Passando por buraco e nunca que chegava nessa delegacia...e eles pegaram a gente no centro e o que mais tem aqui é delegacia. Não parava, não parava, e andava e andava...quando chegou, que parou o carro, eles abriram o camburão, a gente estava no meio do nada, do nada.... gente não via nada, nada...era só terra e mato. Eu não sabia onde a gente estava, daí falaram para gente descer, tiraram as armas e apontaram, assim, para baixo, as armas, e mandaram a gente descer e formar uma fila, daí falaram: 'vou contar até três...e vou mandar vocês correrem...e é para correr mesmo!' Nossa! eu me lembro...daí quando ele contou até três a gente correu, eu me lembro que muito, muito, muito...nisso tinha umas duas na minha frente, eu derrubei, saí assim...atropelando elas. Sabe? A gente saiu uma por cima da outra. A gente corria,

15 São recorrentes, nas narrativas das travestis, as menções à utilização dos cassetetes nos locais com concentração de silicone. Como afirma Lorry: "Muitas meninas são deformadas porque eles batiam no silicone".

16 A afirmação "eles chegavam de repente..." denota frequência. 
mas não queria se separar uma da outra porque a gente não sabia onde estávamos, para a gente não se perder, não ficar só, ficamos juntas, e quando corremos eles atiraram, não sei se foi para cima ou em direção ao morro, só sei que eu corri e fomos parar numa estrada, numa estrada...se não me engano, era Diadema. Eles deixaram a gente lá em Diadema (Laura, para o ano 1997/8).

Passagens por delegacias eram frequentes: "Deixavam a gente...às vezes levavam 20, 15 para delegacia, deixavam a gente trancada, e às vezes só saía três da manhã..." (Lorry); “(...) eu fui, perdi já as contas....quer dizer, eles levam depois soltam”(Laura); “(...) já fui umas três vezes (...) Eu já fui umas três vezes (...) Uma noite, passei uma noite" (Flávia).

Geralmente ir para uma delegacia implicava numa gama de possibilidades, tais como: ficar horas esperando (apenas para preencher algum documento, responder algumas perguntas, geralmente sob o argumento da averiguação etc.), ter que tirar a roupa e ser revistada por homens, ser colocada numa cela até amanhecer, às vezes com vários prisioneiros, ser forçada a fazer sexo com policiais, dentre outras. Subjetivamente isso implicava incerteza, insegurança, pelo que poderia acontecer. Como afirma Laura:

Só a opressão de estar ali, estar passando por aquela situação...(...) me senti acuada, porque eu pensava o que...sei lá, o que poderia acontecer comigo, de eu estar ali...(...) a gente que trabalha na noite, a gente é muito, a gente se sente muito vulnerável, assim... muito... ai! não sei... é uma coisa estranha, é uma coisa estranha, a gente fica ali...a impressão que dá para quem está de fora é que a gente é muito segura, que somos seguras ou que somos protegidas por alguém, mas não, na verdade nós estamos sozinhas.

Geralmente os "recolhimentos em massa”, herança dos arrastões do período da ditadura militar - ou mesmo muito dos aprisionamentos individuais -, embora sob pretexto de averiguação, não se davam, em geral, pelo fato das travestis terem cometido algo ilegal. Constituíam-se em prática constrangedora, rotineira, possivelmente com o objetivo de controlar, amedrontar, dentre outros. Vale aqui também a afirmação de Kulick (2008: 49): "Em qualquer um dos casos as prisões não estavam em absoluto dentro da legalidade: prostituição não é crime no código penal brasileiro, e sobre as travestis detidas não pesava nenhuma acusação (a não ser em algumas ocasiões, quando elas eram acusadas de crime de "vadiagem”)" (aspas no original).

Aliás, como se vê aqui, muitas condutas consideradas ilegais, praticadas por travestis, eram resolvidas também ilegalmente. Ao invés do recolhimento às delegacias, policiais costumavam utilizar doses de violência, violações de direitos, envolvendo extorsões, em muitos casos. Paradoxalmente em muitos casos eram detidas quando não deveriam e em outros não eram detidas quando deveriam (sob o aspecto da legalidade, obviamente). 
Assunto que povoa muitas obras é a propina, o achaque ou situações forjadas (por ex., colocar droga na bolsa) etc. praticadas em benefício de policiais. Como afirma Laura: “(...) e já ter vivenciado, já visto amigas minhas...que policiais já forjaram, colocaram drogas para extorquir, para tirar dinheiro delas e elas terem ficado presas, e eu estando ali..."

Muitas são as possiblidades: permissão para trabalhar, fazer vistas grossas (por ex., deixar as travestis trabalharem nuas mesmo sob reclamações da vizinhança), deixar de prender por ter cometido alguma infração, geralmente em troca de dinheiro ou sexo gratuito. De acordo com Suzi:

(...) trabalhei ali 2 anos. Mas lá, muito complicado. Lá, por exemplo, a gente tinha que trabalhar e dar uma propina para os policiais, porque eles passavam lá; a gente começava a trabalhar desde às 10 até umas 4 da manhã. E você tinha que dar propina para eles, porque se não desse... eles não deixavam você trabalhar lá (...). Todo sábado a gente tinha de dar 40 reais para eles. Eles iam todo sábado, iam pegar 40 reais ${ }^{17}$ (Arujá, segunda metade dos anos 2000).

Aqui mesmo em São Paulo, na República, na Praça da República. Muito complicado. Eu estava transando dentro do carro, aí o policial passou...mas eu estava só fazendo um boquete, não é...? Aí ele falou 'você é gostosa, então você então vai ter que foder com a gente, sem pagar. A gente não vai pagar' Aí tive que fazer (Suzi, segunda metade dos anos 2000) ${ }^{18}$.

Ou, então, a situação vivenciada por Flávia:

A gente estava saindo da boca, onde a gente pegava droga, fui eu e outra travesti. Ele me pegou com 18 trouxinhas de cocaína. Ele podia me levar para delegacia, não é, ser presa, tudo mais...ele só me levou no cantinho, conversou comigo, mas enquanto minha amiga estava apanhando, eu estava chupando o policial...e chupei ele...enquanto minha amiga apanhava do outro... (Flávia, para o ano de 2008).

17 E se a propina não fosse paga? Veja o relato de Suzi: “Teve uma, chamada Rita de Cássia - eu nunca vou esquecer desse nome -, ela não pagou...a gente trabalhava no Trevo, ela não pagou, não pagou...e depois de quatro dias ela apareceu praticamente morta... Isso marcou também minha cabeça...muito difícil....

18 A título de evidência, fato desse tipo consta de relatório do Grupo Gay da Bahia: “Travestis e prostitutas que batalham no Bairro de Indianápolis, em S. Paulo, denunciam que os policiais às prendem e levam para o distrito, só que no meio do caminho obrigam-nas a fazer sexo oral sem o preservativo. Uma delas que foi reclamar, o delegado respondeu que esse tipo de comportamento era bem a cara delas. Depois do sexo costumam ser deixadas em lugares desertos de difícil acesso" (Travestis acusam PM de abuso sexual em SP, Agora São Paulo/SP, 23/7/200o, in Mott \& Cerqueira, 2001: 70). 


\section{A percepção de mudanças}

Eu não viajo muito aqui pelo Brasil, então a única coisa que eu posso te falar é que eu acho que aqui agora está mais tranquilo (Lorry).

Embora violências dos mais variados tipos e violações de direitos cometidos por policiais em relação às travestis continuassem a ocorrer em todo o país, a bibliografia existente a respeito aponta para uma mudança em termos de frequência e intensidade, em algumas localidades ${ }^{19}$, no sentido de uma redução da violência mais contundente por parte dos policiais, ao menos aquela que se dava abertamente e sem constrangimentos. Essa mudança também é apontada por várias travestis "das antigas" com as quais conversei e mesmo as mais novas confirmam, para a cidade de São Paulo. As entrevistadas afirmam o seguinte em relação a essa questão: “(...) hoje é totalmente diferente, eles abordam numa boa, faz o que ele tem que fazer e às vezes ele se despede 'vai tranquilo' (...) Hoje em dia está mamão com mel. Só não pode desrespeitar eles, está entendendo?” (Flávia); “(...) mudou muito, não tem nem comparação (...) melhorou muito, muito mesmo (...) Mas precisa melhorar mais (Laura); “(...) logo no começo, quando eu cheguei em São Paulo, foi muito complicado, muito difícil (...) porque mudou agora (...) Por exemplo, hoje em dia, quando eles abordam a gente na rua já vem uma mulher para abordar a gente...ela mesmo que faz a vistoria na gente" (Suzi). E:

Hoje em dia eles...igual eu te falei Cassiano, está tudo tranquilo não é? tudo beleza. Isso aconteceu em outras épocas...até me emocionei aqui falando contigo, você viu...E hoje em dia, eu acho....não desço mais, igual as meninas, venho de vez em quando (...) eu acho que hoje é tranquilo, hoje está... não sei se tem alguma lei ou se...o que que aconteceu, mas, assim, está bem tranquilo (...) Muito bom para trabalhar agora (...) tenho notado a diferença agora, está muito bom para trabalhar...eu não sei o que aconteceu, entendeu? (Lorry).

Ao serem perguntadas sobre o momento dessa mudança, Flávia acredita que no início dos anos 2000 a situação já começou a melhorar; Laura, mais ou menos, a partir de 2007. Lorry entende que foi na década dos 2000, sendo que quando voltou da França (2005) já percebeu a diferença. As três apontam o que as travestis mais antigas costumam afirmar para São Paulo: a mudança se deu ao longo dos anos 2000, de forma que, entrando-se na atual década, a situação estava alterada, em que pese a continuidade da violência que, na realidade, parece ter mudado de forma e intensidade

19 Sobretudo em grandes cidades, em especial das regiões Sul e Sudeste. 
20. Suzi é a única que destoa, entendendo que a mudança mais significativa se deu a partir de $2015^{21}$. Mas o discurso dela tem que ser relativizado, pois Suzi não trabalha na rua desde 2010 e, portanto, não vivenciou como as demais essa suposta mudança.

$\mathrm{O}$ que parece preocupar hoje, de fato, as travestis mais antigas, na cidade de São Paulo, é a violência entre elas, além da alta rotatividade; costumam reclamar do excesso de roubos, o que prejudica as honestas. Essa afirmação de Laura é muito comum:

(...) antigamente a gente era oprimida mesmo, assim, tinha medo mesmo da polícia. Medo. Hoje em dia não, hoje em dia é entre a gente mesmo, entendeu? Isso, é entre a gente mesmo, porque a gente não confia uma na outra, assim...porque, na verdade, todo dia chegam pessoas diferentes. E a gente vê, entendeu? As coisas acontecerem, entendeu? As novinhas aí chegando, roubando na rua, estragando mais do que...entendeu? (Laura).

Já quando são perguntadas sobre os motivos dessa mudança, afirmam o seguinte: “Teve alguém que, teve alguém que lutou pela gente” (Flávia). E:

Porque mudou, mudou tudo não é? O jeito das pessoas verem as coisas, hoje em dia a gente tem onde procurar, realmente, entendeu? Se acontece alguma coisa com a gente, a gente pode ir até na...os movimentos...(...) agora o mundo, não é? a cidade é monitorada, não é? Todo lugar tem uma câmera...então eles ficam mais...(Laura).

Será que o governo? A internet, a internet...você sabe que a internet mudou muita coisa, não é? (...) Também, a pessoa está mais...o ser humano está mais ligado em tudo, eu acho...aquele medo também de eles estarem fazendo alguma coisa que eles sabem que qualquer pessoa pode estar filmando ali do prédio...é complicado (Lorry).

20 Inclusive a continuidade da ocorrência de assassinatos. Historicamente, durante muitos anos, a única fonte para assassinatos de travestis era o site Quem a homofobia matou hoje (https://homofobiamata. wordpress.com/), do Grupo Gay da Bahia. A partir de 2016 temos também o site Rede Trans Brasil (http://redetransbrasil.org.br) e de 2017 o observatório da violência do Instituto Brasileiro Trans de Educação (http://www.observatoriotrans.org), com foco nas travestis e transexuais. Como a maioria desses crimes carece de investigação conclusiva (em geral os processos são arquivados) uma estatística de assassinatos de travestis cometidos por policiais é algo de difícil elaboração. Temos apenas suspeitas (e às vezes evidências) de que uma parte dos assassinatos tenham sido cometidos por policiais à paisana.

21 "Na década de 90, muita opressão, na década de 2000, um pouquinho, agora, 2015 para 2017, melhorou um pouco. De qualquer forma, acho que nos anos 2000 não mudou tanto em relação aos 1990, continuou violento, a mesma coisa (....) Agora, de 2015 para cá, depois do Projeto Trans. Principalmente porque, por exemplo, agora quando a gente vai numa delegacia, eles geralmente eles mandam a gente para entrada da delegacia das mulheres, porque de primeiro a gente fazia algum B.O na delegacia dos homens. E hoje em dia levam a gente para a delegacia das mulheres, então quando a gente chega lá, elas respeitam a gente pelo nome social, eu achei bem interessante, nesse aspecto. De 2015 para 2017" (Suzi). 
Eu acho que através dos direitos humanos, a pressão dos direitos humanos. E principalmente agora com o projeto Trans. Eu acho que depois que envolveu o projeto Trans, eu acho que os policiais respeitam um pouquinho mais as trans, principalmente na abordagem. Porque geralmente não são eles que abordam, geralmente vem uma outra policial abordar (...) (Suzi) ${ }^{22}$.

Três das entrevistadas mencionam "organizações, movimentos, direitos humanos”, o que está em consonância com o que se observa de fato, isto é, as organizações LGBT (em especial aquelas mais relacionadas às questões da travestilidade) com o tempovêm aumentando consideravelmente seu protagonismo e ganhando eficácia em termos de pressão por políticas públicas assim como em termos de denúncias e monitoramento.

Também duas delas mencionam as mudanças tecnológicas, não só a possibilidade de se saber mais rapidamente o que está acontecendo, de denunciar, mas a possiblidade de se filmar e enviar mensagens on line. De fato, muitas travestis apontam para essa questão. Quer dizer, tudo indica que as mudanças tecnológicas e os movimentos sociais, na área, são, realmente, causas muito prováveis dessa alteração.

A seguinte afirmação de Flávia nos leva ao questionamento sobre uma possível mudança (e seu nível) na visão dos policiais, também:

Mas tem ainda alguns que olham a gente com aquele olhar diferente, mas eles não chegam a falar, está entendendo? Mas, só o olhar é diferente, a gente percebe que ele...está entendendo?... não aceita muito...Ele...como é que se diz? Ele engole, porque ele tem que engolir...e sempre é um, um é tranquilo, aceita numa boa e sempre tem um que já é mais...mas ele não fala nada, se ele não gosta, fica para ele (...) Ainda tem uns que se eles pudessem....

Entendo ser essa reflexão relevante, na conexão com a análise dos motivos dessa mudança. Até que ponto houve orientação explícita ou ordem do comando das polícias em relação à abordagem das travestis? Será que as mudanças relatadas são fruto de mudanças subjetivas dos policiais? Se a resposta for que, em geral, não, então isso significa que a pressão dos movimentos, além das mudanças tecnológicas, fizeram os policiais mudarem sua conduta mesmo contra sua vontade. E, também, será que houveram mudanças nas formações dos policiais (por ex., com mais espaço para disciplinas relacionadas aos direitos humanos e às questões LGBT)? São hipóteses que requerem pesquisas aprofundadas para chegarmos ao cerne da questão.

Para finalizar esta seção, chamo atenção à relação travestis $\mathrm{x}$ policiais no exterior. Das quatro entrevistadas, a única que morou no exterior foi Lorry, nos anos de 2004 e 2005; como ela afirma:

22 Essa colocação nos reporta à importância de pesquisa a respeito do impacto do Projeto Transcidadania sobre as condições de vida das travestis. Lorry capta um outro lado do projeto: “(...) eu graças a esse projeto Transcidadania estou estudando muito e agora eu vejo o mundo com outra visão (...)” 
Na França eu estava ilegal, então o meu medo de polícia era tremendo, bem diferente de eu estar trabalhando no meu país, entendeu? Mas eu acho que a gente não sofreu tanto igual aqui, lá não tem...Olha, não vou te mentir que eu fui presa lá, mas não foi com tanta violência não. Tudo...nossa...tudo...Não fui presa, fiquei...eu fiquei detida... minto, eu não fui presa, fiquei detida na França...e num quartinho de vidro, a gente até brinca que a gente fica parecendo uma boneca na caixa porque é uma salinha toda de vidro e você fica lá dentro. Só que eu não demorei porque não apareceu a tradutora, eu precisava de uma tradutora porque fazia pouco tempo que eu estava na França, não sabia falar. Aí não apareceu a minha tradutora brasileira e eles me dispensaram uma hora da tarde, ou seja, eu fiquei detida de uma da manhã até uma da tarde, na salinha de vidro (risos).

O que Lorry afirma é compartilhado por muitas travestis brasileiras que viveram no exterior. Mesmo na época mais violenta no Brasil, na Europa, em geral (sobretudo nos países mais procurados: Itália, Espanha, França etc.), não há qualquer comparação em relação à abordagem, tratamento etc. Em Albuquerque \& Janelli (1995) essa comparação fica muito evidente, uma vez que a protagonista, a travesti Princesa, sofreu muita violência policial no Brasil e viveu parte de sua vida na Itália, afirmando que se no Brasil, à época, o problema era a violência policial, na Itália era o frio e a droga.

\section{Mas não é só violência...}

(...) porque você sabe que não é só policiais, todo mundo sai com a gente, não tem como... (Lorry)

Com exceção da Lorry ${ }^{23}$, as demais entrevistadas se relacionaram sexualmente e/ou amorosamente com policiais em relações consensuais. Como muitos homens, obviamente há policiais que sentem atração por travestis, assim como elas por eles: "Sim, tem muitos policiais que passam, que eu vejo, que desejam a gente, olham para a gente, com olhar de desejo (...) Mas é muito normal, coisa que é muito normal é a gente sair com policiais, a gente sai...você entendeu? Demais, demais, sair mesmo, fazendo programas, para curtir também, entendeu?" (Laura). E:

(...) pega o telefone da gente...Eu já fiquei com uns, uns que eu gostei, estava com vontade, eu gostei. Peço para ele mostrar o

23 “Cassiano, comigo não... assim, já aconteceu de...lógico, policial 'aí, nossa, tal e aí tal...que você...', aquelas cantadas que aparecem mesmo...mas a gente tira de boa. Assim, nunca aconteceu comigo e eu também nunca, nunca fui para cama com policial em trabalho, sempre trabalhei e eu nunca gostei disso, entendeu?" (Lorry). 
pinto para mim, ele mostra...e eu gosto, aí marca com ele, ele me dá.... porque eu estou com vontade, estou fazendo por prazer, porque a gente tem prazer num militar, eu gosto de homem fardado (Flávia).

Suzi, por exemplo, conta uma transa que teve com um policial, em 2013:

Eu estava na Avenida Paulista, na passeata gay, e quando eu vinha descendo o Trianon Masp apareceu um policial e esse policial, fiquei até com medo porque na hora que eu estava transando com ele, no hotel, estourou a camisinha...não foi programa. Fiquei porque ele era gostoso, poderoso...eu sabia que era um policial e ele pagou o motel...

Há travestis que sentem que há policiais que, ao bater nelas, expressam também atração, mas não conseguem resolver subjetivamente a questão ${ }^{24}$. Fica registrada a complexidade do tema que demanda uma análise mais aprofundada por parte do que sentem e pensam os policiais em relação às travestis. Como afirma Lorry "Eles sentem atração, mas eles batem mesmo assim...não vou te falar que todos, mas...."

Há casos de relacionamentos duradouros entre travestis e policiais, como afirma Laura:

Conheci uma trans que conheceu um policial na rua, e isso foi

Há também, a questão da aproximação consensual com policiais, com vistas a algum objetivo:

Digamos que sim...não é?...e tem os privilégios também, a gente pode passar em frente a uma blitz com uma bandeja...na época que eu usava droga, passar com uma bandeja de cocaína, assim... no colo e ele só descer, mostrar a carteira e entrar tranquilamente, sem precisar, sem ter que estar passando pelo distúrbio de ter que ser revistada, de pedir documento, entendeu? (Laura).

Suzi faz o seguinte relato, depois de um desentendimento com um cliente, em 2005:

24 Numa ocasião uma travesti que levou um murro de um policial me relatou que disse o seguinte para ele: "Você é louco pela gente mas não consegue assumir". 
Eu fui numa delegacia, mas não fiquei presa porque conheci um delegado lá (risos), olha o babado! E o bofe ficou a fim de mim.... então ele disse: 'você sai comigo e a gente não abre um B.O. contra você' (...) Quando cheguei na delegacia o delegado já fez a linha comigo e saí com o bofe. Foi chique e maravilhoso. Aí...graças a Deus rasgou o B.O. (risos) $)^{25}$.

\section{Considerações finais}

Quando você demonstra que você realmente conhece os seus direitos, você procura, eles te tratam de uma forma totalmente diferente (...) As travestis, elas têm os mesmos direitos de todo ser humano. As transexuais também. Eu acho que os policiais também deveriam respeitar um pouquinho.... (Suzi).

Obviamente, as práticas relatadas por quatro travestis não podem expressar todo o universo das relações entre travestis e policiais na cidade de São Paulo ao longo do tempo, no entanto, entendo que pode ajudar a compreender alguns aspectos dessa interação, sobretudo se mais entrevistas, nessa perspectiva, forem realizadas. Lembro, mais uma vez, que muito do que emerge dos discursos das entrevistadas é corroborado pelos conteúdos de obras que relatam ou abordam essas questões, tanto para a cidade de São Paulo (em menor número) como para outras cidades, assim como pelos relatos que já ouvi, ao longo do tempo, de travestis da cidade de São Paulo, de várias idades.

O que se ouve das entrevistadas, em que pese a pequenez da amostra, indica a existência de padrões (de violência, violações e corrupção) de atuação policial que não se constituem em exceções. Até certo momento isso é claramente evidenciado pela despreocupação, por parte dos policiais, com as consequências de suas ações, relevando a impunidade que autoriza a repetição de práticas como se fossem rituais (corredor polonês, abandono em locais longínquos, tirar as travestis das ruas através do recolhimento para averiguação, ganhar com a extorsão etc.).

Lembremos que historicamente as polícias no Brasil se caracterizam pela truculência (violências física e simbólica) e violações de direitos. Para as travestis não é diferente. Como se viu, espancamentos, torturas, agressões dos mais variados tipos etc. quando as vítimas estão sob controle, com uma frequência

${ }_{25}$ Perguntei por que Suzi foi levada à delegacia e ela explicou: "Eu tinha saído com um cliente e a gente tinha acertado um preço (...) A gente tinha acertado um preço e quando chegou lá...eu passei três dias com esse cliente, passei sexta, sábado e domingo... quando foi na segunda de manhã, a gente tinha acertado um preço, só que ele me deu trezentos reais e eu achei um abuso. Aí eu fui no pescoço dele e peguei mesmo, porque eu acho que foi um abuso, se você acerta alguma coisa...(...) quando você acerta um preço... você tem que pagar aquele preço. Ele não me pagou, aí eu peguei mesmo". Essa situação vivenciada por Suzi também tem que ser relativizada, embora ela demonstre certa satisfação, não deixa de se constituir em opressão por parte do delegado e esse pode ser mais um dos discursos da seção 2 na parte referente à propina e ao achaque. 
estonteante, viola flagrantemente os direitos fundamentais, em desacordo com nosso código de leis, inclusive a Constituição ${ }^{26}$, além da crueldade que parte de quem, em tese, deveria defende-las ou evitar violações. O mesmo se pode dizer em relação às práticas de extorsão (achaque, propina etc.) ou os encarceramentos sem justificativa. E mesmo em situações em que poderiam ser legalmente enquadradas, se optou pela solução pessoal dos policiais envolvidos e não pelos procedimentos exigidos por lei, o que demonstra poder quase absoluto para fazer o que quisessem, sabendo que dificilmente seriam punidos. Lembremos também que a prostituição não é crime no Brasil assim como a lei de vadiagem deixou de ter sentido e, na maioria dos casos aqui narrados, nem se pode apelar para o argumento do atentado ao pudor. Também, os recolhimentos para averiguação sempre foram amplamente questionados sob o âmbito legal.

A impunidade que sempre grassou em relação aos policiais responsáveis por essas atrocidades caminha de par com o silêncio e a ausência de indignação de boa parteda sociedade, uma aquiescência moldada numa cultura heteronormativa cheia de preconceitos e estigmas em relação às travestis, que é reforçada por discursos médicos, criminais, morais e religiosos, ainda hoje, inclusive. Lembremos que os policiais estão inscritos nesse código cultural, contribuindo para a criminalização das travestis que acabam sendo vítimas de uma repressão também moral, pois se está a contestar, em geral, o modo de ser travesti. Nesse aspecto as polícias acabam jogando um papel muito importante num possível processo de normalização ${ }^{27}$ que está na confluência do dispositivo da sexualidade ${ }^{28}$. Enfim, se as instituições de segurança pública no Brasil sempre pautaram por uma lógica violenta, violadora e corrupta, quando inscritas num quadro culturalmente heteronormativo e transfóbico, essa conjunção foi sentida (e em parte ainda é) brutalmente pelas travestis brasileiras.

Também, os relatos de que no decorrer dos anos 2000 a violência mais contundente se reduziu, na cidade de São Paulo, devem ser vistos com cuidado, pois isso não significa que a violência e as violações deixaram de ocorrer. Ainda há muitos casos e reclamações em São Paulo e Brasil afora, principalmente em regiões mais longínquas dos grandes centros, onde essa realidade pouco mudou, como se sabe. Ainda há muito por se fazer: “(...) precisa melhorar mais” (Laura).

26 Isso nos leva à indagação: qual o sentido de fazer as travestis sofrerem dessa maneira, quando isso poderia ser evitado?

27 Por normalização, Foucault $(1985,2010)$ entende a imposição da norma (que opõe normais $x$ anormais) não necessariamente por meio da disciplina punitiva, mas, principalmente, por meio de elementos associados ao dispositivo. O autor deu especial atenção ao saber médico e científico quanto a essa questão.

28 "Através deste termo tento demarcar, em primeiro lugar, um conjunto decididamente heterogêneo que engloba discursos, instituições, organizações arquitetônicas, decisões regulamentares, leis, medidas administrativas, enunciados científicos, proposições filosóficas, morais, filantrópicas. Em suma, o dito e o não dito são os elementos do dispositivo. O dispositivo é a rede que se pode estabelecer entre estes elementos" (Foucault, 1979: 244). Evidentemente normalização e dispositivo da sexualidade são conceitos intrinsecamente inter-relacionados. 


\section{Referências}

ALBUQUERQUE, Fernanda Farias de; JANELLI, Maurizio. (1995). A princesa: A história do travesti brasileiro na Europa escrita por um dos líderes da Brigada Vermelha. Rio de Janeiro: Nova Fronteira.

BOURDIEU, Pierre. (1999). A dominação masculina. Rio de Janeiro: Bertrand Brasil.

FERREIRA, Denis Gonçalves. (2016). Conhecendo Violências Sofridas por Travestis que Vivem no Centro de São Paulo. Dissertação (Mestrado em Psicologia Social) Programa de Pós-Graduação em Psicologia Social, Faculdade de Psicologia da Pontifícia Universidade Católica, São Paulo.

FLORENTINO, Cristina de Oliveira. (1998). Bicha, tu tens na barriga, eu sou mulher: Etnografia sobre travestis em Porto Alegre. Dissertação (Mestrado em Antropologia Social) - Programa de Pós-Graduação em Antropologia Social, Faculdade de Antropologia da UFSC, Florianópolis.

FOUCAULT, Michel. (1979). Microfísica do poder. Rio de Janeiro: Edições Graal.

FOUCAULT, Michel. (2010). Os anormais: Curso no Collège de France (1974-1975). São Paulo: Martins Fontes.

FOUCAULT, Michel. 1985). História da sexualidade I: Vontade de saber. 7a edição. Rio de Janeiro: Graal.

KULICK, Don. (2008). Travesti: Prostituição, sexo, gênero e cultura no Brasil. Rio de Janeiro: Editora Fiocruz.

LAMPIÃO DA ESQUINA. (1980). Dois travestis, uma advogada: Três depoimentos vivos sobre o sufoco. Edição extra n.3.

MEIHY, José Carlos Sebe Bom; HOLANDA, Fabíola. (2015). História oral: Como fazer, como pensar. za edição. São Paulo: Contexto.

MOTT, Luiz; CERQUEIRA, Marcelo. (2001). Causa mortis: Homofobia - Violação dos direitos humanos e assassinato de homossexuais no Brasil. Salvador: Grupo Gay da Bahia.

OCANHA, Rafael Freitas. (2014). "Amor, feijão, abaixo camburão": Imprensa, violência e trottoir em São Paulo (1979-1983). Dissertação (Mestrado em História) - Programa de Pós-Graduação em História, Faculdade de História da PUC, São Paulo. 
OLIVEIRA, Marcelo. (1997). O lugar do travesti em Desterro. Dissertação (Mestrado em Antropologia Social) - Programa de Pós-Graduação em Antropologia Social, Faculdade de Antropologia da UFSC, Florianópolis.

OLIVEIRA, Neusa Maria de. (1994). Damas de paus: O jogo aberto dos travestis no espelho da mulher. Salvador: Centro Editorial e Didático da UFBA.

SILVA, Hélio Raimundo Santos. (1993). Travesti: A invenção do feminino. Rio de Janeiro: Relume-Dumará.

SIQUEIRA, Indianare. https://www.facebook.com/indi.siqueira/posts/561252514059561. Acesso em: 30 set. 2017.

THOMPSON, Paul. (1992). A voz do passado. Rio de Janeiro: Paz e Terra.

TREVISAN, João Silvério. (1996). Devassos no paraíso: A homossexualidade no Brasil, da colônia à atualidade. Rio de Janeiro: Record.

Recebido: 09.10.2017

Aceito: 30.06 .2018 